Review

www.mdpi.com/journal/pathogens

\title{
Human Bocavirus: Lessons Learned to Date
}

\section{Oliver Schildgen}

Kliniken der Stadt Köln gGmbH, Krankenhaus Merheim, Klinikum der Privaten Universität Witten/Herdecke, Institut für Pathologie, Ostmerheimer Str. 200, D-51109 Köln (Cologne), Germany; E-Mail: schildgeno@kliniken-koeln.de; Tel.: +49-(0)221-8907-13467; Fax: +49-(0)221-8907-3542

Received: 10 December 2012; in revised form: 8 January 2013 / Accepted: 8 January 2013 / Published: 11 January 2013

\begin{abstract}
Human bocavirus (HBoV) was identified as the second human parvovirus with pathogenic potential in 2005 in respiratory samples from children suffering from viral respiratory infections of unknown etiology. Since its first description, a large number of clinical studies have been performed that address the clinical significance of $\mathrm{HBoV}$ detection and the molecular biology of the virus. This review summarizes the most important steps taken in $\mathrm{HBoV}$ research to date and addresses open questions that need to be answered in the future to provide a better understanding of the role of a virus that is difficult to grow in cell culture and is suspected to be a pathogen, although it has not yet fulfilled Koch's postulates.
\end{abstract}

Keywords: human bocavirus; $\mathrm{HBoV}$; respiratory virus; gastrointestinal virus

\section{Introduction}

For a long time, the number of respiratory infections with clinical symptoms caused by respiratory viruses had no detectable causative agent. With the discovery of human metapneumovirus in 2001 by Bernadette van den Hoogen and her colleagues [1], virus discovery methods have become a focus of virologists, and there has been a marked increase in the number of newly detected viral pathogens. One of those pathogens is human bocavirus $(\mathrm{HBoV})$, which was initially identified by Tobias Allander in 2005 [2] in 17 respiratory samples from children suffering from a respiratory tract disease of suspected viral origin.

Since the discovery of $\mathrm{HBoV}$, numerous studies related to the epidemiology, pathogenesis, and replication of this newly detected virus have been performed, and they have provided novel insights into viral infection of the respiratory tract and gastrointestinal diseases. 


\section{Molecular Biology of $\mathrm{HBoV}$}

Based on sequence analyses of the 17 isolates identified by Allander and coworkers, HBoV was grouped into the family Parvoviridae, subfamily Parvovirinae, and genus Bocavirus. Currently, four subtypes have been identified, and of these, HBoV1 is most frequently detected in clinical samples of the respiratory tract. The remaining isolates are more frequently associated with gastrointestinal infections and symptoms [3-6].

The HBoV genome length ranges from 5,217 to 5,299 nucleotides [4] plus the terminal sequences, which are between 32 and 52 bases [7,8]. Based on phylogenetic analyses and electron microscopy analyses of the $\mathrm{HBoV}$ genomes from clinical specimens, the genome is believed to consist of a single-stranded DNA [9,10] of negative polarity. The negative polarity has been confirmed by real-time NASBA [11]. The terminal sequences, which are assumed to play a crucial role in the initiation of viral replication in the Parvoviridae family, have been identified as linker sequences in episomal genomes or replication intermediates in HBoV1 [7] and HBoV3 [8] and have been shown to have high homology to the terminal sequences of minute virus of canines (MVC) and bovine parvovirus [4], the latter providing a hint about the zoonotic origin of $\mathrm{HBoV}$, either decades or centuries ago.

Recently, Zhao and colleagues showed that the genome of HBoV subtype 2 is circular [12]. This circular nature of the genome raises the question of why the hairpin structures are different between the HBoV subtypes, and it should be determined whether these linker structures are of cellular or other origin.

To date, the genome replication of $\mathrm{HBoV}$ has been assumed to occur in the same manner as the genome replication of animal parvovirus, that is, via a rolling hairpin mechanism, which would generate head-to-head or tail-to-tail intermediates, but the recently detected head-to-tail sequences do not fit with this replication model [7,8]. A novel cell culture system based on NuLi and CuFi cells, immortalized cell lines with the ability to differentiate in an air-liquid interface culture, could be appropriate models in which to study the questions regarding $\mathrm{HBoV}$ replication [13]. This recently published cell culture model is able to support $\mathrm{HBoV}$ replication and produce classical replication forms for parvoviruses; moreover, it was shown that the full-length $\mathrm{HBoV}-1$ genome cloned into a plasmid vector was able to produce infectious particles in stable cells after transfection of the plasmid [13].

It appears likely that $\mathrm{HBoV}$ either persists or uses additional or alternative mechanisms of replication, which remains a matter of speculation.

An alternative replication model could be a helper virus-dependent initiation of rolling circle replication. In a recent case report (below), we identified herpesvirus 6 co-infection in an $\mathrm{HBoV}$ infected patient. Surprisingly, during cidofovir therapy, HHV-6 viremia decreased, and HBoV was eliminated, even though the patient had an underlying immunodeficiency and could not produce neutralizing antibodies [14]. Considering that herpesviruses are able to initiate rolling circle replication [15] and replication that is characterized by head-to-tail sequences in cis and in trans [16], and given that another subfamily of parvoviruses, the dependoviruses, replicate exclusively in the presence of helper viruses, such as herpesviruses [17], this replication model is worth being discussed and investigated further.

The viral transcriptome has been analyzed in 2 studies, which revealed that RNAs for the proteins NS1, NP1, UP1/NP1, VP1/VP2, UP2/VP1/VP2, a putative ORFx protein, and an NS1-70 protein [18,19] 
are most likely transcribed. The genome organization is typical of a member of the Bocavirus genus. The viral genome contains at least three open reading frames (ORFs). Although it has not been experimentally verified for all encoded genes, it is widely assumed and likely that the proteins encoded by the $\mathrm{HBoV}$ genome are similar in function to the proteins of better characterized members of the Bocavirus genus. Thus, the first ORF at the 5 ' end likely encodes a nonstructural protein known as NS1, whereas the subsequent ORF likely encodes a second non-structural protein, NP1, that is believed to be unique to bocaviruses. The third ORF encodes the VP1 and VP2 proteins.

There is currently little information on the interactions of HBoV proteins with each other and with cellular proteins, primarily because secondary reagents, such as $\mathrm{HBoV}$ protein-specific antibodies and a versatile cell culture system, are not available. These materials are necessary for the investigation of such interactions. The novel reverse genetics system published by Huang and colleagues could be a useful tool for the analysis of the functions of HBoV proteins.

Overexpressed VP2 protein is able to form capsid-like structures that strongly resemble viral particles [20]. VP2 particles were used to analyze Th cell immunity by evaluating HBoV-specific T-cell proliferation in T-cells isolated from healthy adults [21]. In contrast to parvovirus B19, HBoV induces a less divergent Th response with respect to proliferation and interferon gamma, IL10 and IL13 production. The NP1 protein was shown to have immunomodulatory effects; using a cell culture approach with a nearly full-length clone of $\mathrm{HBoV}$, Zhang and colleagues have shown that NP1 is able to indirectly block the IFN- $\beta$ promoter and thus inhibit the production of interferon beta [22].

\section{Epidemiology}

$\mathrm{HBoV}$ is a major pathogen detected in respiratory and gastrointestinal infections. To date, four subtypes have been identified, and they are found worldwide, without any regional, geographic, or border restrictions. Following its initial discovery in Sweden, HBoV has been detected all over Europe [5,23-32], North [32-34] and South America [35-39], Africa [40,41], Asia [42-45], and Australia [46-50].

The four distinct subtypes have been named HBoV1-4. Subtype 1 is mainly associated with respiratory diseases, but can also be found in stool samples from patients suffering from diarrhea. The prevalence in symptomatic patients is approximately $1.5-16 \%$ for $\mathrm{HBoV}-1$ [51,52] 21-26\% for HBoV-2 [6], approximately $1 \%$ for HBoV-3 [53], and $0.6 \%$ for HBoV4 [54]. It appears that HBoVs have a high frequency of recombination among each other, as some subtypes are derived from recombinations of two others [6], and novel variants seem to occur more frequently than initially assumed [53].

The seroprevalence of $\mathrm{HBoV}$ is strongly dependent on the age of the investigated patient cohort and ranges from $\sim 40 \%$ in children between 18 and 23 months of age up to virtually $100 \%$ in children older than two years, with an average of $76.6 \%$ in children and $96 \%$ in adults $[55,56]$. The seroprevalence is lowest for HBoV-4 (0.8-5\%), followed by HBoV-3 (10-38.7\%), HBoV-2 (34-49.3\%), and HBoV-1 (66.9-96\%) [55,57].

Recent clinical studies on respiratory infections that used novel multiplexing assays have shown that more severe infections (i.e., infections that are clinically relevant, require hospitalization, and receive a proper laboratory diagnosis) frequently represent co-infections with up to six different pathogens in a single patient [51,52,58-62]. The range of co-infections or, more precisely, the rate of 
co-detection of pathogens that occur simultaneously with $\mathrm{HBoV}$ (or vice versa), ranges from 60 to $90 \%$. This high rate can be explained by the fact that $\mathrm{HBoV}$ can be shed by asymptomatic patients and is able to persist $[7,8,63]$, but it could also be the result of a better study design. During the last several years, it has become impossible to publish a study on respiratory viruses without screening for all viruses known at the time of the study. This requirement is one reason why the aforementioned studies used multiplexing technology and revealed marked frequencies of double or multiple infections (up to $44 \%$ ) independent of the pathogens investigated [51,52,58-62]. Therefore, HBoV is not exclusively a bystander, but rather, the study cohorts investigated in the past (mainly hospitalized patients) suffered from multiple infections more frequently than previously assumed.

\section{Pathogenesis}

In contrast to other viruses, from the first clinical studies until the present, $\mathrm{HBoV}$ has been co-detected with more additional pathogens than any other respiratory virus. This fact led to the hypothesis that $\mathrm{HBoV}$ may be a harmless bystander rather than a true pathogen, a hypothesis that was supported by the fact that it is impossible to fulfill Koch's postulates for HBoV due to technical restrictions, i.e., currently, neither a versatile cell culture system nor an animal model has been established, nor have there been documented cases of the human-to-human transmission of HBoV.

There is currently limited information about the pathogenesis of $\mathrm{HBoV}$. HBoV can be found in respiratory tract secretions [27] and stool [64-66]. HBoV also causes viremia (i.e., during active replication, the virus is detectable in the blood/serum of infected patients [55,67-73]). Furthermore, $\mathrm{HBoV}$ can be found in the duodenum [14], paranasal sinus mucosa [74], and intestinal biopsies [8]. Considering that in organ-specific air-liquid interface cell culture [18], HBoV particles were secreted both apically and distally, i.e., into the air phase and the liquid phase (which mimics the bloodstream), the most likely model for $\mathrm{HBoV}$ pathogenicity is a model analogous to that for minute virus of canines. This virus enters the host via the respiratory tract, reaches the bloodstream, and enters the gastrointestinal tract via the bloodstream or ingestion. Finally, viral shedding takes place via either coughing or defecation [75]. This model of pathogenesis is supported by the fact that the seroprevalence of $\mathrm{HBoV}$ is highest for the respiratory subtype $\mathrm{HBoV} 1$, whereas HBoV2-4 are less frequent and less seroprevalent [55].

Currently, it appears that all age groups can be affected by $\mathrm{HBoV}$, although severe infections and infections requiring hospitalization occur primarily in patients with an underlying disease [76-83]. Severe clinical cases have been described in children [76,77], adults with cancer [76] and other risk groups [84].

\section{Treatment}

There is currently no specific approved treatment for $\mathrm{HBoV}$ infection [85]. Symptomatic treatment may be required in severe cases and is analogous to the treatment of other respiratory tract infections. To date, there has been only a single case report in which antiviral treatment was associated with the elimination of $\mathrm{HBoV}$ in a patient co-infected with HBoV and HHV-6 [14]. The boy suffered from an immunodeficiency and had lost the ability to mount an antibody-based immune response. During treatment with cidofovir, which is specific for herpesviruses, HHV-6 viremia decreased, and the HBoV 
infection was successfully eliminated. The outcome of this case is consistent with the outcome of another clinical case that we observed, in which $\mathrm{HBoV}$ viremia decreased during treatment, although this case had a fatal outcome for other reasons [86].

It must also be mentioned that, due to the lack of an animal model and a versatile cell culture system, the development of a vaccine is extremely difficult, and therefore, no results of such efforts have been published. The prevention methods for $\mathrm{HBoV}$ infection are analogous to those of other respiratory virus infections, and for laboratory research, this virus is "treated" in the same manner as other parvoviruses. The German National Committee for Biologic Safety (Zentralkommission für Biologische Sicherheit, ZKBS) has consequently classified this virus as a biosafety level 2 agent.

\section{Diagnosis}

Due to the lack of a cell culture system, the diagnosis of $\mathrm{HBoV}$ infection is exclusively based on molecular detection methods. Most laboratories currently use in-house PCR and real-time PCR assays targeting the NP-1, NS-1 or VP1/2 gene [3], but other nucleic acid-based detection methods for the diagnosis of $\mathrm{HBoV}$ have been described [11]. A number of commercially available approved multiplexing assays have been developed and brought to the market. Some of these assays also detect human bocavirus, including the Luminex RVP assay (Luminex, USA) and the RespiFinder assay (Pathofinder, the Netherlands). It appears likely that other assays to detect $\mathrm{HBoV}$ will be developed, although in many currently available assays, such as the FilmArray (Idaho Diagnostics, USA) and the RespID assay (Luminex, USA), this pathogen is neglected. Of note, for those laboratories that follow FDA rules, it is important to keep in mind that the Luminex RVP xTAG fast assay has received FDA clearance, whereas the other assays with FDA approval do not detect human bocavirus.

To correctly diagnose an $\mathrm{HBoV}$ infection, it is necessary to screen clinical samples from the respiratory tract or stool samples (depending on whether the primary symptoms are respiratory or gastrointestinal) and a corresponding serum sample [31,67-70,72]. The latter is of great importance, as viremia is observed only during active infection [31,67-70,72,87,88], whereas $\mathrm{HBoV}$ can be shed by otherwise healthy patients, most likely due to persistent infection without viremia $[87,88]$.

\section{Conclusions}

Although it was discovered several years ago, there are still more questions than answers related to human bocavirus. Despite an increasing and overwhelming amount of evidence that the virus is in fact a pathogen, Koch's modified postulates have not yet been fulfilled for HBoV, primarily because a versatile cell culture system and an animal model are not available. Moreover, the virus is frequently detected as a co-pathogen, primarily because with the discovery of $\mathrm{HBoV}$, a new era of clinical studies of respiratory infections has begun. In these studies, patients are screened for virtually all viruses known at the time the studies are performed. Currently, the primary challenge of the HBoV community is to develop a cell culture system or an animal model in which the virus can be propagated. The most recently published cell culture system using $\mathrm{CuFi}$ and $\mathrm{NuLi}$ cells could be such a model.

These tools are a prerequisite for the search for answers to open questions, including questions regarding effective antivirals and disinfectants and the molecular pathogenesis of HBoV. These tools 
will also help to determine whether $\mathrm{HBoV}$ is in fact a serious pathogen and not simply part of the harmless microbiome of its hosts.

Based on the currently available data, until $\mathrm{HBoV}$ can be proven to be a harmless bystander, I recommend that $\mathrm{HBoV}$ be treated as a pathogen, and thus, an inverse presumption of innocence should apply for $\mathrm{HBoV}$.

If one tries to follow the history of virus discoveries during the last decade and has performed clinical studies in the field of respiratory infections, it is obvious that with the increasing number of identified pathogens, the range of diagnostic tools required in a clinical study has also increased. Thus, the more known viruses there are, the more diagnostic assays are demanded by investigators, clinicians, and peer reviewers of the manuscripts that describe those studies. It thus remains unknown whether $\mathrm{HBoV}$ is in fact a pathogen or whether the co-detection rate was high because clinical studies on $\mathrm{HBoV}$ infections were among the first generation of studies in which the presence of virtually all respiratory pathogens was required to be assessed.

\section{Acknowledgments}

This work was supported by a grant from Else Kröner-Fresenius Stiftung, Germany (P48/09//A95/09).

\section{Conflict of Interest Statement}

The author declares no conflict of interest.

\section{References}

1. van den Hoogen, B.G.; de Jong, J.C.; Groen, J.; Kuiken, T.; de Groot, R.; Fouchier, R.A.; Osterhaus, A.D. A newly discovered human pneumovirus isolated from young children with respiratory tract disease. Nat. Med. 2001, 7, 719-724.

2. Allander, T.; Tammi, M.T.; Eriksson, M.; Bjerkner, A.; Tiveljung-Lindell, A.; Andersson, B. Cloning of a human parvovirus by molecular screening of respiratory tract samples. Proc. Natl. Acad. Sci. USA 2005, 102, 12891-12896.

3. Schildgen, O.; Muller, A.; Allander, T.; Mackay, I.M.; Volz, S.; Kupfer, B.; Simon, A. Human bocavirus: Passenger or pathogen in acute respiratory tract infections? Clin. Microbiol. Rev. 2008, 21, 291-304.

4. Schildgen, O.; Qiu, J.; Soderlund-Venermo, M. Genomic features of the human bocaviruses. Future Virol. 2012, 7, 31-39.

5. Volz, S.; Schildgen, O.; Klinkenberg, D.; Ditt, V.; Muller, A.; Tillmann, R.L.; Kupfer, B.; Bode, U.; Lentze, M.J.; Simon, A. Prospective study of human bocavirus (hbov) infection in a pediatric university hospital in germany 2005/2006. J. Clin. Virol. 2007, 40, 229-235.

6. Kapoor, A.; Simmonds, P.; Slikas, E.; Li, L.; Bodhidatta, L.; Sethabutr, O.; Triki, H.; Bahri, O.; Oderinde, B.S.; Baba, M.M.; et al. Human bocaviruses are highly diverse, dispersed, recombination prone, and prevalent in enteric infections. J. Infect. Dis. 2010, 201, 1633-1643. 
7. Lusebrink, J.; Schildgen, V.; Tillmann, R.L.; Wittleben, F.; Bohmer, A.; Muller, A.; Schildgen, O. Detection of head-to-tail DNA sequences of human bocavirus in clinical samples. PLoS One 2011, 6, e19457.

8. Kapoor, A.; Hornig, M.; Asokan, A.; Williams, B.; Henriquez, J.A.; Lipkin, W.I. Bocavirus episome in infected human tissue contains non-identical termini. PLoS One 2011, 6, e21362.

9. Brieu, N.; Gay, B.; Segondy, M.; Foulongne, V. Electron microscopy observation of human bocavirus (hbov) in nasopharyngeal samples from hbov-infected children. J. Clin. Microbiol. 2007, 45, 3419-3420.

10. Gurda, B.L.; Parent, K.N.; Bladek, H.; Sinkovits, R.S.; DiMattia, M.A.; Rence, C.; Castro, A.; McKenna, R.; Olson, N.; Brown, K.; et al. Human bocavirus capsid structure: Insights into the structural repertoire of the parvoviridae. J. Virol. 2010, 84, 5880-5889.

11. Bohmer, A.; Schildgen, V.; Lusebrink, J.; Ziegler, S.; Tillmann, R.L.; Kleines, M.; Schildgen, O. Novel application for isothermal nucleic acid sequence-based amplification (NASBA). J. Virol. Methods 2009, 158, 199-201.

12. Zhao, H.; Zhao, L.; Sun, Y.; Qian, Y.; Liu, L.; Jia, L.; Zhang, Y.; Dong, H. Detection of a bocavirus circular genome in fecal specimens from children with acute diarrhea in beijing, china. PLoS One 2012, 7, e48980.

13. Huang, Q.; Deng, X.; Yan, Z.; Cheng, F.; Luo, Y.; Shen, W.; Lei-Butters, D.C.; Chen, A.Y.; Li, Y.; Tang, L.; et al. Establishment of a reverse genetics system for studying human bocavirus in human airway epithelia. PLoS Pathog. 2012, 8, e1002899.

14. Streiter, M.; Malecki, M.; Prokop, A.; Schildgen, V.; Lusebrink, J.; Guggemos, A.; Wisskirchen, M.; Weiss, M.; Cremer, R.; Brockmann, M.; et al. Does human bocavirus infection depend on helper viruses? A challenging case report. Virol. J. 2011, 8, 417.

15. Gerspach, R.; Matz, B. Herpes simplex virus-induced "rolling circle" amplification of sv40 DNA sequences in a transformed hamster cell line correlates with tandem integration of the sv40 genome. Virology 1989, 173, 723-727.

16. Matz, B. Herpes simplex virus causes amplification of recombinant plasmids containing simian virus 40 sequences. J. Gen. Virol. 1989, 70 ( Pt 6), 1347-1358.

17. Ward, P.; Falkenberg, M.; Elias, P.; Weitzman, M.; Linden, R.M. Rep-dependent initiation of adeno-associated virus type 2 DNA replication by a herpes simplex virus type 1 replication complex in a reconstituted system. J. Virol. 2001, 75, 10250-10258.

18. Dijkman, R.; Koekkoek, S.M.; Molenkamp, R.; Schildgen, O.; van der Hoek, L. Human bocavirus can be cultured in differentiated human airway epithelial cells. J. Virol. 2009, 83, 7739-7748.

19. Chen, A.Y.; Cheng, F.; Lou, S.; Luo, Y.; Liu, Z.; Delwart, E.; Pintel, D.; Qiu, J. Characterization of the gene expression profile of human bocavirus. Virology 2010, 403, 145-154.

20. Gurda, B.L.; Parent, K.N.; Bladek, H.; Sinkovits, R.; DiMattia, M.A.; Rence, C. Human bocavirus capsid structure: Insights into the structural repertoire of the parvoviridae. J. Virol. 2012, 84, 5880-5889. 
21. Kumar, A.; Filippone, C.; Lahtinen, A.; Hedman, L.; Soderlund-Venermo, M.; Hedman, K.; Franssila, R. Comparison of th-cell immunity against human bocavirus and parvovirus b19: Proliferation and cytokine responses are similar in magnitude but more closely interrelated with human bocavirus. Scand. J. Immunol. 2011, 73, 135-140.

22. Zhang, Z.; Zheng, Z.; Luo, H.; Meng, J.; Li, H.; Li, Q.; Zhang, X.; Ke, X.; Bai, B.; Mao, P.; et al. Human bocavirus np1 inhibits ifn-beta production by blocking association of ifn regulatory factor 3 with ifnb promoter. J. Immunol. 2012, 189, 1144-1153.

23. Bonzel, L.; Tenenbaum, T.; Schroten, H.; Schildgen, O.; Schweitzer-Krantz, S.; Adams, O. Frequent detection of viral coinfection in children hospitalized with acute respiratory tract infection using a real-time polymerase chain reaction. Pediatr. Infect. Dis. J. 2008, 27, 589-594.

24. Kleines, M.; Scheithauer, S.; Rackowitz, A.; Ritter, K.; Hausler, M. High prevalence of human bocavirus detected in young children with severe acute lower respiratory tract disease by use of a standard pcr protocol and a novel real-time per protocol. J. Clin. Microbiol. 2007, 45, 1032-1034.

25. Modrow, S.; Wenzel, J.J.; Schimanski, S.; Schwarzbeck, J.; Rothe, U.; Oldenburg, J.; Jilg, W.; Eis-Hubinger, A.M. Prevalence of nucleic acid sequences specific for human parvoviruses, hepatitis a and hepatitis e viruses in coagulation factor concentrates. Vox Sang. 2011, 100, 351-358.

26. Weissbrich, B.; Neske, F.; Schubert, J.; Tollmann, F.; Blath, K.; Blessing, K.; Kreth, H.W. Frequent detection of bocavirus DNA in german children with respiratory tract infections. $B M C$ Infect. Dis. 2006, 6, 109.

27. Allander, T.; Jartti, T.; Gupta, S.; Niesters, H.G.; Lehtinen, P.; Osterback, R.; Vuorinen, T.; Waris, M.; Bjerkner, A.; Tiveljung-Lindell, A.; et al. Human bocavirus and acute wheezing in children. Clin. Infect. Dis. 2007, 44, 904-910.

28. Fabbiani, M.; Terrosi, C.; Martorelli, B.; Valentini, M.; Bernini, L.; Cellesi, C.; Cusi, M.G. Epidemiological and clinical study of viral respiratory tract infections in children from italy. $J$. Med. Virol. 2009, 81, 750-756.

29. Terrosi, C.; Fabbiani, M.; Cellesi, C.; Cusi, M.G. Human bocavirus detection in an atopic child affected by pneumonia associated with wheezing. J. Clin. Virol. 2007, 40, 43-45.

30. Garcia-Garcia, M.L.; Calvo, C.; Pozo, F.; Perez-Brena, P.; Quevedo, S.; Bracamonte, T.; Casas, I. Human bocavirus detection in nasopharyngeal aspirates of children without clinical symptoms of respiratory infection. Pediatr. Infect. Dis. J. 2008, 27, 358-360.

31. Soderlund-Venermo, M.; Lahtinen, A.; Jartti, T.; Hedman, L.; Kemppainen, K.; Lehtinen, P.; Allander, T.; Ruuskanen, O.; Hedman, K. Clinical assessment and improved diagnosis of bocavirus-induced wheezing in children, finland. Emerg. Infect. Dis. 2009, 15, 1423-1430.

32. Longtin, J.; Bastien, M.; Gilca, R.; Leblanc, E.; de Serres, G.; Bergeron, M.G.; Boivin, G. Human bocavirus infections in hospitalized children and adults. Emerg. Infect. Dis. 2008, 14, 217-221.

33. Albuquerque, M.C.; Pena, G.P.; Varella, R.B.; Gallucci, G.; Erdman, D.; Santos, N. Novel respiratory virus infections in children, brazil. Emerg. Infect. Dis. 2009, 15, 806-808.

34. Bastien, N.; Brandt, K.; Dust, K.; Ward, D.; Li, Y. Human bocavirus infection, canada. Emerg. Infect. Dis. 2006, 12, 848-850. 
35. Flores, C.J.; Vizcaya, A.C.; Araos, B.R.; Montecinos, P.L.; Godoy, M.P.; Valiente-Echeverria, F.; Perret, P.C.; Valenzuela, C.P.; Hirsch, B.T.; Ferres, G.M. Human bocavirus in chile: Clinical characteristics and epidemiological profile in children with acute respiratory tract infections. Rev. Chilena Infectol. 2011, 28, 504-511.

36. Pilger, D.A.; Cantarelli, V.V.; Amantea, S.L.; Leistner-Segal, S. Detection of human bocavirus and human metapneumovirus by real-time pcr from patients with respiratory symptoms in southern brazil. Mem. Inst. Oswaldo Cruz 2011, 106, 56-60.

37. Ghietto, L.M.; Camara, A.; Camara, J.; Adamo, M.P. High frequency of human bocavirus 1 DNA in infants and adults with lower acute respiratory infection. J. Med. Microbiol. 2012, 61, 548-551.

38. Ghietto, L.M.; Camara, A.; Zhou, Y.; Pedranti, M.; Ferreyra, S.; Frey, T.; Camara, J.; Adamo, M.P. High prevalence of human bocavirus 1 in infants with lower acute respiratory tract disease in argentina, 2007-2009. Braz. J. Infect. Dis. 2012, 16, 38-44.

39. Salmon-Mulanovich, G.; Sovero, M.; Laguna-Torres, V.A.; Kochel, T.J.; Lescano, A.G.; Chauca, G.; Sanchez, J.F.; Rodriguez, F.; Parrales, E.; Ocana, V.; et al. Frequency of human bocavirus (hbov) infection among children with febrile respiratory symptoms in argentina, nicaragua and peru. Influenza Other Respi. Viruses 2011, 5, 1-5.

40. Carrol, E.D.; Mankhambo, L.A.; Guiver, M.; Banda, D.L.; Group, I.P.D.S.; Denis, B.; Dove, W.; Jeffers, G.; Molyneux, E.M.; Molyneux, M.E.; et al. Pcr improves diagnostic yield from lung aspiration in malawian children with radiologically confirmed pneumonia. PLoS One 2011, 6, e21042.

41. Smuts, H.; Workman, L.; Zar, H.J. Role of human metapneumovirus, human coronavirus n163 and human bocavirus in infants and young children with acute wheezing. J. Med. Virol. 2008, 80, 906-912.

42. Chieochansin, T.; Samransamruajkit, R.; Chutinimitkul, S.; Payungporn, S.; Hiranras, T.; Theamboonlers, A.; Poovorawan, Y. Human bocavirus (hbov) in thailand: Clinical manifestations in a hospitalized pediatric patient and molecular virus characterization. J. Infect. 2008, 56, 137-142.

43. Khamrin, P.; Malasao, R.; Chaimongkol, N.; Ukarapol, N.; Kongsricharoern, T.; Okitsu, S.; Hayakawa, S.; Ushijima, H.; Maneekarn, N. Circulating of human bocavirus 1, 2, 3, and 4 in pediatric patients with acute gastroenteritis in thailand. Infect. Genet. Evol. 2012, 12, 565-569.

44. Pham, N.T.; Trinh, Q.D.; Chan-It, W.; Khamrin, P.; Nishimura, S.; Sugita, K.; Maneekarn, N.; Okitsu, S.; Mizuguchi, M.; Ushijima, H. Human bocavirus infection in children with acute gastroenteritis in japan and thailand. J. Med. Virol. 2011, 83, 286-290.

45. Lau, S.K.; Yip, C.C.; Que, T.L.; Lee, R.A.; Au-Yeung, R.K.; Zhou, B.; So, L.Y.; Lau, Y.L.; Chan, K.H.; Woo, P.C.; et al. Clinical and molecular epidemiology of human bocavirus in respiratory and fecal samples from children in hong kong. J. Infect. Dis. 2007, 196, 986-993.

46. Arden, K.E.; Chang, A.B.; Lambert, S.B.; Nissen, M.D.; Sloots, T.P.; Mackay, I.M. Newly identified respiratory viruses in children with asthma exacerbation not requiring admission to hospital. J. Med. Virol. 2010, 82, 1458-1461.

47. Arden, K.E.; McErlean, P.; Nissen, M.D.; Sloots, T.P.; Mackay, I.M. Frequent detection of human rhinoviruses, paramyxoviruses, coronaviruses, and bocavirus during acute respiratory tract infections. J. Med. Virol. 2006, 78, 1232-1240. 
48. Arthur, J.L.; Higgins, G.D.; Davidson, G.P.; Givney, R.C.; Ratcliff, R.M. A novel bocavirus associated with acute gastroenteritis in australian children. PLoS Pathog. 2009, 5, e1000391.

49. Sloots, T.P.; McErlean, P.; Speicher, D.J.; Arden, K.E.; Nissen, M.D.; Mackay, I.M. Evidence of human coronavirus hku1 and human bocavirus in australian children. J. Clin. Virol. 2006, 35, 99-102.

50. Tozer, S.J.; Lambert, S.B.; Whiley, D.M.; Bialasiewicz, S.; Lyon, M.J.; Nissen, M.D.; Sloots, T.P. Detection of human bocavirus in respiratory, fecal, and blood samples by real-time pcr. $J$. Med. Virol. 2009, 81, 488-493.

51. Arnott, A.; Vong, S.; Rith, S.; Naughtin, M.; Ly, S.; Guillard, B.; Deubel, V.; Buchy, P. Human bocavirus amongst an all-ages population hospitalised with acute lower respiratory infections in cambodia. Influenza Other Respi. Viruses 2012, doi: 10.1111/j.1750-2659.2012.00369.x.

52. Do, A.H.; van Doorn, H.R.; Nghiem, M.N.; Bryant, J.E.; Hoang, T.H.; Do, Q.H.; Van, T.L.; Tran, T.T.; Wills, B.; Nguyen, V.C.; et al. Viral etiologies of acute respiratory infections among hospitalized vietnamese children in ho chi minh city, 2004-2008. PLoS One 2011, 6, e18176.

53. Cashman, O.; O'Shea, H. Detection of human bocaviruses 1, 2 and 3 in irish children presenting with gastroenteritis. Arch. Virol. 2012, 157, 1767-1773.

54. Koseki, N.; Teramoto, S.; Kaiho, M.; Gomi-Endo, R.; Yoshioka, M.; Takahashi, Y.; Nakayama, T.; Sawada, H.; Konno, M.; Ushijima, H.; et al. Detection of human bocaviruses 1 to 4 from nasopharyngeal swab samples collected from patients with respiratory tract infections. J. Clin. Microbiol. 2012, 50, 2118-2121.

55. Kantola, K.; Hedman, L.; Arthur, J.; Alibeto, A.; Delwart, E.; Jartti, T.; Ruuskanen, O.; Hedman, K.; Soderlund-Venermo, M. Seroepidemiology of human bocaviruses 1-4. J. Infect. Dis. 2011, 204, 1403-1412.

56. Hustedt, J.W.; Christie, C.; Hustedt, M.M.; Esposito, D.; Vazquez, M. Seroepidemiology of human bocavirus infection in jamaica. PLoS One 2012, 7, e38206.

57. Guo, L.; Wang, Y.; Zhou, H.; Wu, C.; Song, J.; Li, J.; Paranhos-Baccala, G.; Vernet, G.; Wang, J.; Hung, T. Differential seroprevalence of human bocavirus species 1-4 in beijing, china. PLoS One 2012, 7, e39644.

58. Babady, N.E.; Mead, P.; Stiles, J.; Brennan, C.; Li, H.; Shuptar, S.; Stratton, C.W.; Tang, Y.W.; Kamboj, M. Comparison of the luminex xtag rvp fast assay and the idaho technology filmarray rp assay for detection of respiratory viruses in pediatric patients at a cancer hospital. J. Clin. Microbiol. 2012, 50, 2282-2288.

59. Balada-Llasat, J.M.; LaRue, H.; Kelly, C.; Rigali, L.; Pancholi, P. Evaluation of commercial resplex ii v2.0, multicode-plx, and xtag respiratory viral panels for the diagnosis of respiratory viral infections in adults. J. Clin. Virol. 2011, 50, 42-45.

60. De Vos, N.; Vankeerberghen, A.; Vaeyens, F.; Van Vaerenbergh, K.; Boel, A.; De Beenhouwer, H. Simultaneous detection of human bocavirus and adenovirus by multiplex real-time pcr in a belgian paediatric population. Eur. J. Clin. Microbiol. Infect. Dis. 2009, 28, 1305-1310.

61. Lassauniere, R.; Kresfelder, T.; Venter, M. A novel multiplex real-time rt-pcr assay with fret hybridization probes for the detection and quantitation of 13 respiratory viruses. J. Virol. Methods 2010, 165, 254-260. 
62. Loeffelholz, M.J.; Pong, D.L.; Pyles, R.B.; Xiong, Y.; Miller, A.L.; Bufton, K.K.; Chonmaitree, T. Comparison of the filmarray respiratory panel and prodesse real-time pcr assays for detection of respiratory pathogens. J. Clin. Microbiol. 2011, 49, 4083-4088.

63. Martin, E.T.; Fairchok, M.P.; Kuypers, J.; Magaret, A.; Zerr, D.M.; Wald, A.; Englund, J.A. Frequent and prolonged shedding of bocavirus in young children attending daycare. J. Infect. Dis. 2010, 201, 1625-1632.

64. Campe, H.; Hartberger, C.; Sing, A. Role of human bocavirus infections in outbreaks of gastroenteritis. J. Clin. Virol. 2008, 43, 340-342.

65. Han, T.H.; Kim, C.H.; Park, S.H.; Kim, E.J.; Chung, J.Y.; Hwang, E.S. Detection of human bocavirus-2 in children with acute gastroenteritis in south korea. Arch. Virol. 2009, 154, 1923-1927.

66. Kapoor, A.; Slikas, E.; Simmonds, P.; Chieochansin, T.; Naeem, A.; Shaukat, S.; Alam, M.M.; Sharif, S.; Angez, M.; Zaidi, S.; et al. A newly identified bocavirus species in human stool. $J$. Infect. Dis. 2009, 199, 196-200.

67. Don, M.; Soderlund-Venermo, M.; Hedman, K.; Ruuskanen, O.; Allander, T.; Korppi, M. Don't forget serum in the diagnosis of human bocavirus infection. J. Infect. Dis. 2011, 203, 1031-1032; author reply 1032-1033.

68. Don, M.; Soderlund-Venermo, M.; Valent, F.; Lahtinen, A.; Hedman, L.; Canciani, M.; Hedman, K.; Korppi, M. Serologically verified human bocavirus pneumonia in children. Pediatr. Pulmonol. 2010, 45, 120-126.

69. Hedman, L.; Soderlund-Venermo, M.; Jartti, T.; Ruuskanen, O.; Hedman, K. Dating of human bocavirus infection with protein-denaturing igg-avidity assays-secondary immune activations are ubiquitous in immunocompetent adults. J. Clin. Virol. 2010, 48, 44-48.

70. Kantola, K.; Hedman, L.; Allander, T.; Jartti, T.; Lehtinen, P.; Ruuskanen, O.; Hedman, K.; Soderlund-Venermo, M. Serodiagnosis of human bocavirus infection. Clin. Infect. Dis. 2008, 46, 540-546.

71. Korner, R.W.; Soderlund-Venermo, M.; van Koningsbruggen-Rietschel, S.; Kaiser, R.; Malecki, M.; Schildgen, O. Severe human bocavirus infection, germany. Emerg. Infect. Dis. 2011, 17, 2303-2305.

72. Korppi, M.; Jartti, T.; Hedman, K.; Soderlund-Venermo, M. Serologic diagnosis of human bocavirus infection in children. Pediatr. Infect. Dis. J. 2010, 29, 387.

73. Nascimento-Carvalho, C.M.; Cardoso, M.R.; Meriluoto, M.; Kemppainen, K.; Kantola, K.; Ruuskanen, O.; Hedman, K.; Soderlund-Venermo, M. Human bocavirus infection diagnosed serologically among children admitted to hospital with community-acquired pneumonia in a tropical region. J. Med. Virol. 2012, 84, 253-258.

74. Falcone, V.; Ridder, G.J.; Panning, M.; Bierbaum, S.; Neumann-Haefelin, D.; Huzly, D. Human bocavirus DNA in paranasal sinus mucosa. Emerg. Infect. Dis. 2011, 17, 1564-1565.

75. Tijssen, P. Molecular and structural basis of the evolution of parvovirus tropism. Acta Vet. Hung. 1999, 47, 379-394.

76. Kupfer, B.; Vehreschild, J.; Cornely, O.; Kaiser, R.; Plum, G.; Viazov, S.; Franzen, C.; Tillmann, R.L.; Simon, A.; Muller, A.; et al. Severe pneumonia and human bocavirus in adult. Emerg. Infect. Dis. 2006, 12, 1614-1616. 
77. Heydari, H.; Mamishi, S.; Khotaei, G.T.; Moradi, S. Fatal type 7 adenovirus associated with human bocavirus infection in a healthy child. J. Med. Virol. 2011, 83, 1762-1763.

78. Antunes, H.; Rodrigues, H.; Silva, N.; Ferreira, C.; Carvalho, F.; Ramalho, H.; Goncalves, A.; Branca, F. Etiology of bronchiolitis in a hospitalized pediatric population: Prospective multicenter study. J. Clin. Virol. 2010, 48, 134-136.

79. Calvo, C.; Garcia-Garcia, M.L.; Pozo, F.; Carvajal, O.; Perez-Brena, P.; Casas, I. Clinical characteristics of human bocavirus infections compared with other respiratory viruses in spanish children. Pediatr. Infect. Dis. J. 2008, 27, 677-680.

80. Deng, Y.; Gu, X.; Zhao, X.; Luo, J.; Luo, Z.; Wang, L.; Fu, Z.; Yang, X.; Liu, E. High viral load of human bocavirus correlates with duration of wheezing in children with severe lower respiratory tract infection. PLoS One 2012, 7, e34353.

81. Franz, A.; Adams, O.; Willems, R.; Bonzel, L.; Neuhausen, N.; Schweizer-Krantz, S.; Ruggeberg, J.U.; Willers, R.; Henrich, B.; Schroten, H.; et al. Correlation of viral load of respiratory pathogens and co-infections with disease severity in children hospitalized for lower respiratory tract infection. J. Clin. Virol. 2010, 48, 239-245.

82. Smuts, H.; Hardie, D. Human bocavirus in hospitalized children, south africa. Emerg. Infect. Dis. 2006, 12, 1457-1458.

83. Vallet, C.; Pons-Catalano, C.; Mandelcwajg, A.; Wang, A.; Raymond, J.; Lebon, P.; Gendrel, D. Human bocavirus: A cause of severe asthma exacerbation in children. J. Pediatr. 2009, 155, 286-288.

84. Muller, A.; Klinkenberg, D.; Vehreschild, J.; Cornely, O.; Tillmann, R.L.; Franzen, C.; Simon, A.; Schildgen, O. Low prevalence of human metapneumovirus and human bocavirus in adult immunocompromised high risk patients suspected to suffer from pneumocystis pneumonia. $J$. Infect. 2009, 58, 227-231.

85. Jartti, T.; Soderlund-Venermo, M.; Allander, T.; Vuorinen, T.; Hedman, K.; Ruuskanen, O. No efficacy of prednisolone in acute wheezing associated with human bocavirus infection. Pediatr. Infect. Dis. J. 2011, 30, 521-523.

86. Klinkenberg, D.; Schneppenheim, R.; Müller, I.; Blohm, M.; Malecki, M.; Schildgen, V.; Schildgen, O. Fatal human bocavirus infection in a boy with ipex-like syndrome and vaccineacquired rotavirus enteritis awaiting stem cell transplantation. Arch. Dis. Child. 2012, 97, A274.

87. Bonvicini, F.; Manaresi, E.; Gentilomi, G.A.; Di Furio, F.; Zerbini, M.; Musiani, M.; Gallinella, G. Evidence of human bocavirus viremia in healthy blood donors. Diagn. Microbiol. Infect. Dis. 2011, 71, 460-462.

88. Martin, E.T.; Taylor, J.; Kuypers, J.; Magaret, A.; Wald, A.; Zerr, D.; Englund, J.A. Detection of bocavirus in saliva of children with and without respiratory illness. J. Clin. Microbiol. 2009, 47, 4131-4132.

(C) 2013 by the authors; licensee MDPI, Basel, Switzerland. This article is an open access article distributed under the terms and conditions of the Creative Commons Attribution license (http://creativecommons.org/licenses/by/3.0/). 